\title{
Heritability, Genetic Advance and Path Coefficient Analysis for Grain Yield and its Component Characters in Soybean (Glycine max L. Merrill)
}

\author{
Tadesse Ghiday*, A. Amogne ${ }^{1}$ G. Tefera $^{1}$, M.Malede ${ }^{1}$ \\ *Holetta Agricultural Research Center P.O.Box 31, Holetta, Ethiopia. \\ ${ }^{1}$ Pawe Agricultural Research Center, Ethiopia
}

\begin{abstract}
Twenty two promising new and three checks of Soybean (Glycine max L. Merrill) genotypes were grown in two successive seasons of 2014/2015 and 2015/2016 to assess the presence of variability for desired traits and amount of variation for different parameters. Genetic parameters, correlations, and partial regressions were estimated for all the traits. Analysis of variance showed significant differences among entries for all the characters. The estimates of genotypic coefficient of variation $(G C V)$ and phenotypic coefficient of variation $(P C V)$ were high for grain yield per plant, biological yield and number of seeds per pod. Broad sense heritability estimates for various traits ranged from 74.62 to $99.73 \%$. Grain yield per plant showed high significant positive genetic and phenotypic correlation with number of pods per plant and number of seeds per pod. Multiple correlations of characters (0.36), via, number of pods per plant, number of primary branches and number of seeds per pod which were significant with grain yield were far from the multiple correlations of all characters (0.96). The total variability calculated through multiple correlation in the population for yield improvement accounted by number of pods per plant, number of primary branches and number of seeds per pod was $36 \%$ compared to $96 \%$ accounted by all other characters. It was concluded that more number of pods per plant, number of primary branches and number of seeds per pod are major yield contributing factors in selecting high yielding soybean cultivars. Highly significant positive correlations, with the highest positive direct effect were observed for the number of pods per plant followed by the number of primary branches per plant. Therefore, the number of pods per plant and number of primary branches per plant can be considered as critical criteria for improving yield.
\end{abstract}

Keywords: Phenotypic, Genotypic, Coefficient, Variation, Genetic advance, Heritability, Path Coefficient, Soybean.

\section{INTRODUCTION}

Soybean (Glycine max (L.) Merrill) is the most important vegetable food sources in the world. In Ethiopia, soybean is an introduced crop and had a higher expansion of cultivated area in recent years, with crop production of 636531 quintal of harvest with average of productivity 19.98 quintal per hectare in 2013/2014cropping season [1]. National average yield is very low compared with its potential and yields obtained in other soybean producing countries. It is largely grown in the lowlands of the country and constitutes roughly $2-3 \%$ of the annual pulse production and plays an appreciable role in human nutrition and health, edible oil, livestock feed and many other industrial and pharmaceutical applications [2].

Understanding the magnitude of existing variability, proper characterization of the most important physiological traits and their interrelationships with yield and yield components would be extremely helpful in the synthesis of most efficient and highly productive genotypes [3]. So, soybean improvement depends on the continuous supply of new germplasm as donors of various genes of agronomic importance. The development of high yielding-cultivars is the main objective of any breeding programs in the world [4]. One of the main objectives of any breeding program is to produce high-yielding and better-quality lines for release as cultivars to farmers. The prerequisite to achieve this goal is to find sufficient amount of variability, in which desired lines are to be selected for further manipulation to achieve the target. Introduction of new populations can be made from one region to the other easily and may be used for further manipulation to develop new breeding lines [5]. 
Identification of better genotypes with desirable traits and their subsequent use in breeding program and establishment of suitable selection criteria can be helpful for successful varietals improvement program. Analysis of variability among the traits and the association of a particular character in relation to other traits contributing to yield of a crop would be of great importance in planning a successful breeding program [6][7]. Development of high-yielding cultivars requires a thorough knowledge of the existing genetic variation for yield and its components. The observed variability is a combined estimate of genetic and environmental causes, of which only the former one is heritable. However, estimates of heritability alone do not provide an idea about the expected gain in the next generation, but have to be considered in conjunction with estimates of genetic advance, the change in mean value among successive generations [8]. A survey of genetic variability with the help of suitable parameters such as genetic coefficient of variation, heritability estimates and genetic advance are absolutely necessary to start an efficient breeding program [9]. Assessment of the extent of genetic variability within soybean, is fundamental for soybean breeding programs and the conservation of genetic resources, and is particularly useful as a general guide in the choice of parents for breeding hybrids. The objectives of the present study were to assess and evaluate genetic variability of soybean germplasm based on agro-morphological traits.

\section{MATERIAL AND MethodS}

Twenty two promising new and three checks of Soybean (Glycine max L. merrill) genotypes from IITA/Nigeria were used. Gisham, Awassa-95 and Belessa-95 were the checks. Entry number, genotype, seed source, and year are presented in Table 1. The experiment was conducted at Pawe Agricultural Research Center (PARC), North West of Ethiopia from 2014/2015 to 2015/2016 rainfed season in a randomized complete block design (RCBD) with three replications, each plot with four rows of $0.40 \mathrm{~m}$ width and $5 \mathrm{~m}$ row length. Sowing was done by hand drilling at a seed rate of 70 $\mathrm{kg} / \mathrm{ha}$. The spacing between plots and replication were $0.40 \mathrm{~m}$ and $1 \mathrm{~m}$, respectively. Di ammonium phosphate (DAP) fertilizer was applied at the rate of $100 \mathrm{~kg} / \mathrm{ha}$. All the cultural practices were performed as recommended. The plant data during the cropping season and after harvesting were recorded. The seed yield per plot and biological yield per plot were measured by taking a net plot of $0.8 \mathrm{~m} \times 5 \mathrm{~m}$ or $4 \mathrm{~m}^{2}$ and this was used to determine harvest index. All other characters were recorded on a single plant basis by randomly taking five plants from each experimental plot.

Table 1. Entry number, genotype, seed source, and year

\begin{tabular}{|l|l|l|l|l|l|l|l|}
\hline Entry No & Genotype & Source & Year & Entry No & Genotype & Source & Year \\
\hline 1 & TGX 1987-35F & IITA/Nigeria & 2007 & 14 & TGX 1987-40F & IITA/Nigeria & 2011 \\
\hline 2 & TGX 1987-11F & IITA/Nigeria & 2007 & 15 & TGX 1987-38F & IITA/Nigeria & 2007 \\
\hline 3 & TGX 1740-2F & IITA/Nigeria & 2006 & 16 & TGX 1987-37F & ITTA/Nigeria & 2007 \\
\hline 4 & TGX 1987-9F & IITA/Nigeria & 2007 & 17 & TGX 1987-14F & IITA/Nigeria & 2011 \\
\hline 5 & TGX 1987-23F & IITA/Nigeria & 2007 & 18 & TGX 1987-10F & IITA/Nigeria & 2007 \\
\hline 6 & TGX1987-64F & IITA/Nigeria & 2011 & 19 & TGX 1987-65F & IITA/Nigeria & 2011 \\
\hline 7 & TGX 1987-62F & IITA/Nigeria & 2011 & 20 & TGX 1989-59F & IITA/Nigeria & 2007 \\
\hline 8 & TGX1987-15F & IITA/Nigeria & 2006 & 21 & TGX 1987-18F & IITA/Nigeria & 2007 \\
\hline 9 & TGX 1986-3F & IITA/Nigeria & 2005 & 22 & TGX 1987-20F & IITA/Nigeria & 2007 \\
\hline 10 & TGX 1987-36F & IITA/Nigeria & 2011 & 23 & GISHAMA & ITTA/Nigeria & 2005 \\
\hline 11 & TGX 1987-19F & IITA/Nigeria & 2011 & 24 & AWASSA95 & IITA/Nigeria & 2004 \\
\hline 12 & TGX 1935-10E & IITA/Nigeria & 2005 & 25 & BELESSA95 & IITA/Nigeria & 2005 \\
\hline 13 & TGX 1987-34F & IITA/Nigeria & 2007 & & & & \\
\hline
\end{tabular}

\subsection{Weather Condition}

The precipitation and average temperature for the 2014/2015 and 2015/2016 cropping seasons in Pawe Agricultural Research Center farm field are presented in Table 2. Total precipitation in $2014 / 2015$ was $1242.2 \mathrm{~mm}$, while it was $1351.9 \mathrm{~mm}$ in 2015/2016.

Table 2. Distribution of rainfall and temperature regimes during the seasons.

\begin{tabular}{|l|l|l|l|l|}
\hline \multirow{2}{*}{ Month } & Rainfall $(\mathrm{mm})$ & Temperature ${ }^{\circ} \mathrm{C}$ & $2015 / 2016$ \\
\cline { 2 - 5 } & $2014 / 2015$ & $2015 / 2016$ & $2014 / 2015$ & 27.85 \\
\hline May & 181.6 & 68.7 & 27.1 & 24.7 \\
\hline June & 132.3 & 270.3 & 24.9 & \\
\hline
\end{tabular}


Heritability, Genetic Advance and Path Coefficient Analysis for Grain Yield and its Component Characters in Soybean (Glycine max L. Merrill)

\begin{tabular}{|l|l|l|l|l|}
\hline \hline July & 231.2 & 340.1 & 23.25 & 22.95 \\
\hline August & 367.8 & 338.1 & 22.6 & 22.9 \\
\hline September & 248.6 & 242.4 & 23.4 & 23.3 \\
\hline October & 80.5 & 85.9 & 24.15 & 24.5 \\
\hline November & 0.2 & 6.4 & 23.35 & 23.6 \\
\hline Total & 1242.2 & 1351.9 & & \\
\hline
\end{tabular}

\subsection{Character Studied}

The characters measured included biological yield pert plant (g) (BY), grain yield per plant (g) (GY), plant height $(\mathrm{cm})(\mathrm{PH})$, number of primary branches (NPRB), number of pods per plant(NPP), number of seeds per pod (NSP), Hundred seed weight (g) (HSW), number of days to flower (DF), number of days to maturity (DM), grain filling period (GFP) and harvest index (HI).

\subsection{Statistical Analysis}

Analysis of variance, using randomized complete block design, was computed for all the characters evaluated using the computer software system of SAS (SAS Institute, 2002).

\section{RESULTS}

\subsection{Phenoty pic Variation}

The results from analyses of variance over two years for the investigated characteristics are presented in Table 3. Grain yield and some yield component characteristics of the twenty two promising new soybean genotypes and three check cultivars which were introduced from IITA were assessed in a two year study and a high significant variability among the promising soybean genotypes were determined with respect to the studied parameters (Table 4). Effects of cultivar (V) and year (Y) were found to be significant for all the parameters, except for the effect of year of grain yield per plant, biological yield, harvest index, and hundred seed weight. However, the interaction of $\mathrm{Y} \times \mathrm{V}$ was not significant. The mean values of the characteristics studied are shown in Table 5.

Table 3. Analysis of variance form applied for combined data of two seasons

\begin{tabular}{|c|c|c|c|}
\hline Source of variation & $\mathrm{df}$ & MS & Expected MS \\
\hline Season (s) & $\mathrm{s}-1$ & - & - \\
\hline Rep. within season & $\mathrm{s}(\mathrm{r}-1)$ & - & - \\
\hline Cultivars (V) & $\mathrm{g}-1$ & $\mathrm{MS} 1$ & $\sigma^{2} \mathrm{e}^{2} \sigma^{2} \mathrm{gs}+\mathrm{sr} \sigma_{\mathrm{g}}^{2}$ \\
\hline $\mathrm{V} \times \mathrm{S}$ & $(\mathrm{s}-1)(\mathrm{g}-1)$ & $\mathrm{MS} 2$ & $\sigma^{2} \mathrm{e}+\mathrm{r} \sigma^{2} \mathrm{gs}$ \\
\hline Pooled error & $\mathrm{S}(\mathrm{r}-1)(\mathrm{g}-1)$ & $\mathrm{MS} 3$ & $\sigma_{\mathrm{e}}^{2}$ \\
\hline
\end{tabular}

Table 4. Analysis of variance for biological yield per plant $(B Y)$, grain yield per plant $(G Y)$, harvest index per plant (HI), Number of primary branches (PRBP), number of pods per plant(NPP), Number of seeds per pod $(N S P)$, hundred seed weight $(H S W)$, plant height $(P H)$, flowering date $(D F)$, maturity date (DM) and grain filling period (GFP) of 25 soybean genotypes grown under field conditions

\begin{tabular}{|c|c|c|c|c|c|c|c|c|c|c|c|}
\hline \multirow[b]{2}{*}{$\begin{array}{l}\text { Source } \\
\text { of } \\
\text { variance }\end{array}$} & \multicolumn{11}{|c|}{ Mean square } \\
\hline & BY & GY & $\mathrm{HI}$ & PRBP & NPP & NSP & HSW & $\mathrm{PH}$ & $\mathrm{DF}$ & DM & GFP \\
\hline $\begin{array}{l}\text { Season } \\
\text { (S) }\end{array}$ & 0.01 & 0.47 & 318.34 & $2.08 * *$ & $648.88 * *$ & $333.75 * *$ & 16.52 & $449.31 * *$ & * $187.91 * *$ & $848.88 * *$ & $* 238.01 * *$ \\
\hline $\begin{array}{c}\text { Rep. } \\
\text { within } \\
\text { season }\end{array}$ & $\begin{array}{c}34.68 \\
* *\end{array}$ & $7.68 * *$ & * $716.41 * *$ & $3.32 * *$ & $144.26 * *$ & 6.03 & 4.35 & $40.61 * *$ & $22.11 * *$ & $164.26 * *$ & $* 84.86 * *$ \\
\hline $\begin{array}{l}\text { Cultivars } \\
\text { (V) }\end{array}$ & $\begin{array}{c}15.76 \\
* *\end{array}$ & $3.77 * *$ & * $209.58 * *$ & $1.30 * *$ & $1053.52 * *$ & $661.52 * *$ & $* 330.25 * *$ & $635.93 * *$ & * $138.06 * *$ & $253.52 * *$ & * $177.33 * *$ \\
\hline $\mathrm{V} \times \mathrm{S}$ & 0.75 & 0.01 & 39.88 & 0.33 & 11.70 & 7.92 & 17.67 & 11.46 & 3.68 & 13.70 & 13.51 \\
\hline $\begin{array}{l}\text { Pooled } \\
\text { error }\end{array}$ & 1.91 & 0.80 & 101.07 & 0.31 & 6.14 & 10.10 & 20.23 & 11.57 & 3.65 & 11.14 & 13.70 \\
\hline
\end{tabular}


Tadesse Ghiday et al.

Table 5. Variation for 11 characters in 25 soybean genotypes and mean values of check cultivars.

\begin{tabular}{|c|c|c|c|c|c|c|c|c|}
\hline \multirow[b]{2}{*}{ Variable } & \multirow[b]{2}{*}{ Range } & \multirow[b]{2}{*}{ Mean \pm SE } & \multirow{2}{*}{$\begin{array}{l}\text { Std } \\
\text { Dev }\end{array}$} & \multirow{2}{*}{$\begin{array}{l}\text { F.values for } \\
\text { genotype }\end{array}$} & \multirow{2}{*}{$\begin{array}{l}\text { LSD (P- } \\
0.05)\end{array}$} & \multicolumn{3}{|c|}{ Check cultivars } \\
\hline & & & & & & GISHAMA & A|AWASSA95 & BELESSA95 \\
\hline BY & $2.00-14.25$ & $6.92 \pm 0.79$ & 02.06 & $08.24 * *$ & 01.57 & 6.66 & 6.32 & 7.59 \\
\hline GY & $0.58-7.65$ & $3.04 \pm 0.51$ & 01.09 & $04.72 * *$ & 01.02 & 2.99 & 2.78 & 3.41 \\
\hline $\mathrm{HI}$ & $9.5-84.4$ & $44.23 \pm 5.80$ & 10.65 & $00.39^{* *}$ & 11.42 & 44.88 & 44.35 & 45.94 \\
\hline PRBP & $1-5$ & $02.47 \pm 0.32$ & 00.71 & $04.28 * *$ & 00.63 & 02.17 & 02.75 & 02.38 \\
\hline NPP & $79-97$ & $79.11 \pm 1.96$ & 10.76 & $4.95^{* *}$ & 03.87 & 65.25 & 63.33 & 67.83 \\
\hline \begin{tabular}{|l|} 
NSP \\
\end{tabular} & $3-4$ & $2.9 \pm 0.83$ & 0.86 & $3.45 * *$ & 0.61 & 3.71 & 2.51 & 2.9 \\
\hline HSW & $24.97-79.2$ & $48.34 \pm 2.59$ & 08.42 & $16.33^{* *}$ & 05.11 & 50.79 & 51.44 & 45.44 \\
\hline $\mathrm{PH}$ & $39-91$ & $64.11 \pm 1.96$ & 10.76 & $54.95^{* *}$ & 03.87 & 62.25 & 66.33 & 61.83 \\
\hline $\mathrm{DF}$ & $106-139$ & $116.12 \pm 1.10$ & 05.13 & $37.80^{* * *}$ & 02.17 & 116.75 & 112.25 & 119.04 \\
\hline DM & $123-178$ & $143.05 \pm 1.92$ & 207.36 & $22.74 * *$ & 03.79 & 141.92 & 140.79 & 148.17 \\
\hline GFP & $12-48$ & $26.93 \pm 2.14$ & 06.44 & $13.74 * *$ & 04.21 & 25.71 & 28.54 & 29.13 \\
\hline
\end{tabular}

\subsection{Promising Soybean Genotypes Vs Standard Cultivars}

Comparisons between the promising soybean genotypes and the improved cultivars showed that, in general, promising soybean genotypes were similar to the check cultivars except for number of seed per pod and flowering date. Check cultivar (GISHAMA) has greater number of seed per pod than the promising soybean genotypes. Also, BELESSA95 check was later in flowering than other promising soybean genotypes. The mean values of other characters compared to the check cultivars are presented in Table 5. There was one promising soybean genotype TGX1987-40F that was superior to the check GISHAMA for grain yield per plant. The grain yield and other characters of the superior plant and check cultivars are presented in Table 6. Among yield components, this genotype TGX1987-40F was better than the check in number pods per plant, number seed per pod and number of primary branches.

Table 6. Mean values of grain yield components of examined genotypes of soybean

\begin{tabular}{|c|c|c|c|c|c|c|c|c|c|c|c|c|}
\hline No. & Genotype & BY & GY & HI & PRBP & NPP & NSP & HSW & $\mathrm{PH}$ & DF & DM & GFP \\
\hline 1 & TGX 1987-35F & 06.12 & 1.83 & 29.87 & 1.67 & 79.00 & 2.1 & 38.51 & 47.00 & 131.67 & 158.67 & 27.00 \\
\hline & TGX & & & & & & 1.7 & & & & & \\
\hline & & & & & & & & & & & & \\
\hline & & & & & & & 2. & & & & & \\
\hline & & & .34 & 4 & 2.33 & & 2.0 & 16 & & & & 14.83 \\
\hline & & 5.87 & 2.77 & 47.18 & 2.50 & 86.17 & 2.8 & 32.49 & 6.1 & 15.17 & 36.67 & 21.50 \\
\hline & & 5.73 & 2.94 & 51.34 & 3.33 & 86.33 & 2.4 & 38.80 & 56.33 & & & 21.17 \\
\hline & & 05.21 & 2.12 & 40.59 & 2.33 & 82.67 & 2.3 & 37.54 & 52.67 & & & 19.67 \\
\hline & & & 7 & & 2. & & 2. & & & & & 26.92 \\
\hline 10 & & & 74 & & 3.00 & & 2.2 & +1.4 & 8.0 & & & 17.50 \\
\hline 11 & & 7.07 & .02 & 42.68 & 3.50 & 89.17 & 2.0 & 43.15 & 59.17 & & 144.27 & 27.43 \\
\hline 12 & & .34 & 4.95 & 43.69 & 2.83 & 86.17 & 3.5 & 46.78 & 66.17 & & .67 & 37.00 \\
\hline 13 & & 08.57 & 03.83 & 44.68 & 2.67 & 69.33 & 3.5 & 43.41 & 69.33 & & & 24.67 \\
\hline 14 & & 09.62 & 05.07 & 52.66 & 3.50 & 97.00 & 4.0 & 51.68 & 72.00 & & & 29.17 \\
\hline 15 & & & 1 & & 2.67 & & 3.4 & 46.2 & 69.3 & & & 26.17 \\
\hline 16 & & .69 & 36 & & 3.33 & 93.8 & 3.7 & 45.59 & 38 & & & 28.00 \\
\hline 17 & & 10.69 & 04.97 & .53 & 2.17 & 96.33 & 3.5 & 42.80 & 76.3. & 14.67 & 33 & 29.67 \\
\hline 18 & & .30 & 4.42 & 42.92 & 2.50 & 89.33 & 3.6 & 40.80 & 59.33 & 16.83 & 141.50 & 24.67 \\
\hline 19 & & 7.35 & 02.31 & .40 & 1.50 & 92.00 & 3.2 & 47.94 & 72.00 & & 142.50 & 29.17 \\
\hline 20 & & 08.71 & 4.93 & 56.58 & 3.17 & 89.33 & 2.9 & 42.71 & 69.33 & 113.83 & 140.00 & 26.17 \\
\hline 21 & & 09.15 & 4.73 & 51.70 & 3.00 & 93.83 & 2.6 & 46.17 & 63.83 & 50 & 144.50 & 28.00 \\
\hline 22 & & & & & 2.8 & & 2.8 & & & & & 29.67 \\
\hline 23 & & & .15 & & 1.5 & & 3.6 & 48 & .17 & & & 17.00 \\
\hline 24 & & & 2.6 & & 2.67 & & 1.8 & 48.72 & .00 & & & 28.83 \\
\hline 25 & BELESSA 95 & 03.97 & 2.11 & 53.15 & 1.67 & 67.83 & 3.0 & 41.66 & 8.17 & 125.33 & 142.67 & 17.33 \\
\hline
\end{tabular}

\subsection{Genetic Variability}

In trying to determine the extent to which variation in yield components are responsible for differences in yield among various cultivars, it must be borne in mind that overall variability depends on heritable and non-heritable components. While coefficients of variation measure the magnitude 
Heritability, Genetic Advance and Path Coefficient Analysis for Grain Yield and its Component Characters in Soybean (Glycine max L. Merrill)

of variability present in a population, estimates of heritability and genetic advances are important preliminary steps in any breeding program as they provide information needed in designing the most effective breeding program and the relative practicability of selection. Genotypic variance, phenotypic variance, genotypic coefficient of variability (GCV), phenotypic coefficient of variability (PCV), broad sense heritability, genetic advance and genetic advance expressed as percentage of mean for 11 characters are presented in Table 7.

Table 7. Genetic parameters for some characteristics in soybean genotypes grown during two seasons 2014/15 and 2015/16 under field conditions.

\begin{tabular}{|l|l|l|l|l|l|l|l|l|l|l|l|}
\hline $\begin{array}{l}\text { Source } \\
\text { of variance }\end{array}$ & BY & GY & HI & PRBP & NPP & NSP & HSW & PH & DF & DM & GFP \\
\hline$\sigma^{2}$ g & 2.50 & 0.63 & 28.28 & 0.16 & 107.22 & 108.93 & 52.10 & 104.08 & 22.40 & 39.97 & 27.30 \\
\hline$\sigma^{2}$ p & 2.63 & 0.632 & 34.93 & 0.22 & 114.82 & 110.25 & 55.04 & 105.9 & 23.01 & 42.25 & 29.56 \\
\hline Heritability\% & 95.24 & 99.73 & 80.97 & 74.62 & 93.38 & 98.80 & 94.65 & 98.20 & 97.33 & 94.60 & 92.38 \\
\hline GCV $(\%)$ & 22.86 & 26.04 & 12.02 & 16.28 & 21.24 & 35.24 & 14.93 & 15.91 & 4.08 & 4.42 & 19.40 \\
\hline PCV $(\%)$ & 23.42 & 26.07 & 13.36 & 18.85 & 21.98 & 35.45 & 15.35 & 16.06 & 4.13 & 4.54 & 20.19 \\
\hline GA & 3.18 & 1.63 & 9.86 & 0.72 & 20.61 & 21.37 & 14.47 & 20.83 & 9.62 & 12.67 & 10.35 \\
\hline GAM & 45.95 & 53.57 & 22.29 & 28.97 & 42.28 & 72.15 & 29.92 & 32.48 & 8.28 & 8.85 & 38.42 \\
\hline \multicolumn{10}{|c|}{ * Significant at the 0.05 probability level. } \\
\hline
\end{tabular}

\subsection{Estimates of Heritability}

The results showed considerable phenotypic and genotypic variances among the genotypes for the traits under consideration. In all traits a large portion of the phenotypic variance was accounted for by the genetic component and the contributions of genetic variance to phenotypic variance were more than 74\% (Table 7). The estimates of GCV were high for number of seeds per pod (35.24), grain yield per plant (26.04), biological yield per plant (22.86), number of pods per plant (21.24), grain filling period (19.40), number of primary branches (16.28), and plant height (15.91). The remaining traits recorded moderate to low GCV estimates. The PCV values were higher than GCV values for all the traits which reflect the influence of environment on the expression of traits. The results of heritability indicated that moderate heritability values were recorded for number of primary branches per plant, while high heritability estimates for other yield components (Table 8).

Table 8. Genotypic (Bold) and phenotypic correlations among different quantitative characters in soybean.

\begin{tabular}{|c|c|c|c|c|c|c|c|c|c|c|c|}
\hline & BY & GY & $\mathrm{HI}$ & PRBP & NPP & NSP & HSW & $\mathrm{PH}$ & DF & DM & GFP \\
\hline BY & 1 & $0.92 * *$ & $-0.22 * *$ & $0.60 * *$ & $-063 * *$ & $0.71 * *$ & $0.18 * *$ & $0.71 * *$ & $-0.16 * *$ & $0.42 * *$ & $0.66 * *$ \\
\hline GY & $0.98 * *$ & 1 & $0.17 * *$ & $0.68 * *$ & $0.88 * *$ & $0.77 * *$ & $0.27 * *$ & $0.55 * *$ & $-0.30 * *$ & $0.26 * *$ & $0.60 * *$ \\
\hline HI & $-0.11 * *$ & $0.49 * *$ & 1 & $0.14 * *$ & 0.45 & $0.14 * *$ & $0.29 * *$ & $-0.34 * *$ & $-0.51 * *$ & $-0.53 * *$ & $-0.18 * *$ \\
\hline PRBP & $0.31 * *$ & $0.33 * *$ & $0.08 *$ & 1 & -0.831 *⿻ & $0.12 * *$ & 0.10 ** & $0.29 * *$ & $-0.20 * *$ & $-0.05 * *$ & $0.24 * *$ \\
\hline NPP & $-0.7 .1^{* *}$ & $0.91 * *$ & $-0.78 * *$ & $0.851^{* *}$ & 1 & -0.239 & 0.541 & -0.556 & -0.091 & -0.074 & $0.56 * *$ \\
\hline NSP & $0.53 * *$ & $0.52 * *$ & 0.08 & 0.07 & 0.39 & 1 & $-0.06 * *$ & $0.42 * *$ & $-0.13 * *$ & $0.40 * *$ & $\mathbf{0 . 6 0} * *$ \\
\hline $\mathrm{HSW}$ & $0.15 * *$ & $0.33 * *$ & $0.15 * *$ & 0.03 & 0.67 & -0.04 & 1 & $0.27 * *$ & $-0.41 * *$ & $-.16 * *$ & $0.17 * *$ \\
\hline $\mathrm{PH}$ & $0.50 * *$ & $0.35 * *$ & $-0.11 * *$ & $0.18 * *$ & $-0.53 * *$ & $0.38 * *$ & $0.22 * *$ & 1 & $-0.34 * *$ & $0.20 * *$ & $0.56 * *$ \\
\hline $\mathrm{DF}$ & $-0.12 * *$ & $0.15 * *$ & $-0.18 * *$ & $-0.09 * *$ & $0.32 * *$ & $-0.10 * *$ & $-0.33 * *$ & $-0.28 * *$ & 1 & $0.59 * *$ & -0.19 \\
\hline $\mathrm{DM}$ & $0.28 * *$ & $0.15 * *$ & $-0.20 * *$ & 0.006 & $0.41 * *$ & $0.33 * *$ & $-0.13 * *$ & $0.17 * *$ & $0.51 * *$ & 1 & $0.68 * *$ \\
\hline GFP & $0.41 * *$ & $0.31^{* *}$ & $-0.09 * *$ & 0.08 & $0.73 * *$ & $0.46 * *$ & $0.12 * *$ & $0.42 * *$ & -0.21 & $0.73 * *$ & 1 \\
\hline
\end{tabular}

\subsection{Estimates of Expected Genetic Advance}

The expected genetic advance values for 11 characters of the genotypes evaluated is presented in Table 7. These values are also expressed as percentage of the genotypes mean for each character so that comparison could be made among various characters, which had different units of measurement. High heritability along with high genetic advance is an important factor for predicting the resultant effect for selecting the best individuals. Number of seeds per pod, grain yield per plant, biological yield, number of pods per plant, grain filling period, plant height, and hundred seed weight had high 
heritability accompanied with high genetic advance, while maturity date, flowering date and harvest index had high heritability coupled with low genetic advance.

\subsection{Genotypic and Phenotypic Correlations among Characters}

The phenotypic and genotypic correlations for morpho-agronomic traits are presented in Table 8 . Number of pods per plant and number of seeds per pod which are the main component of grain yield gave the highest positive significant phenotypic and genotypic association with grain yield per plant implying that improving these characters could result in high grain yield. Since yield of grain is the product of number of pods per plant, number of seeds per pod, and hundred seed weight, all assume importance in efforts to attain new levels of productivity in soybean. Number of primary branches per plant had a highly significant genotypic correlation with grain yield but had low phenotypic correlation. The significant positive correlation of primary branches per plant with yield per plant has been reported by Arshad [10] and that of number of pods per plant and number of seeds per pod by Baraskar [11]. Physio-morphological trait, i.e. plant height ranked second after yield components (Number of pods per plant, number of seeds per pod and number of primary branches per plant) in their positive associations with grain yield. A positive association between grain yield and grain filling period was obtained. On the contrary, grain yield had strong negative correlation $(\mathrm{P}<0.01)$ with days to flowering.

\subsection{Multiple Correlation and Regression Analysis}

In order to determine the effect of morphological traits on grain yield, multiple correlation analyses were carried out (Table 9). The joint association through multiple correlations of all characters studied with yield was highly significant. Multiple correlations of characters (0.36), via number of pods per plant, number of primary branches and number of seeds per pod, which were significant with grain yield were far from the multiple correlation of all characters $(0.96)$.

The significance of partial regression coefficients was also tested (Table 10). Partial regression analysis of grain yield on the basis of all yield components are given in Table 10. Yield showed a significant partial regression coefficient with number of pods per plant, number of primary branches and flowering date. The selection of best regression equation done through backward elimination procedure showed that number of pods per plant, number of primary branches, number of seeds per pod and flowering date were the most effective variables contributing to the grain yield. The partial regression coefficients of number of pods per plant $(0.584)$, number of primary branches $(0.47)$ and number of seeds per pod (0.05) were significant (Table 10).

Table 9. Multiple correlation analysis of grain yield per plant on the basis of all yield components (Col. 1) and on the basis of number of primary branches and number of seeds per pod (Col. 2)

\begin{tabular}{|l|l|l|}
\hline & Col. 1 & Col. 2 \\
\hline Multiple correlation & & \\
\hline Coefficient of determination $\left(\mathrm{R}^{2}\right)$ & 0.9635 & 0.3638 \\
\hline Adjusted R-square & 0.9629 & 0.3616 \\
\hline Standard error & 0.2214 & 0.8773 \\
\hline
\end{tabular}

** Significant at 0.01 Level

Table 10a. Partial regression analysis of grain yield with its components in soybean genotypes

\begin{tabular}{|l|l|l|l|}
\hline Yield component & Partial regression coefficient (B) & S.E (B) & “ $\mathrm{t}$ " \\
\hline Number of Primary branches & $0.0584^{* *}$ & 0.01534 & 3.81 \\
\hline Number of pods per plant & $0.0362^{* *}$ & 0.01301 & 2.72 \\
\hline Number of seed per pod & $0.00244^{*}$ & 0.00109 & 2.24 \\
\hline Hundred seed weight & 0.00004 & 0.00115 & 0.41 \\
\hline Plant height & -0.0008 & 0.0010 & -0.81 \\
\hline Flowering date & $0.0038^{*}$ & 0.0016 & 2.32 \\
\hline Maturity date & 0.0030 & 0.0023 & 1.27 \\
\hline
\end{tabular}

*,** Significant at 0.05 and 0.01 level, respectively 
Heritability, Genetic Advance and Path Coefficient Analysis for Grain Yield and its Component Characters in Soybean (Glycine max L. Merrill)

Table 10b. Partial regression analysis of grain yield with Number of primary branches and number of seeds per pod in soybean genotypes

\begin{tabular}{|l|l|l|l|}
\hline Yield component & Partial regression coefficient (B) & S.E (B) & “" $t$ ” \\
\hline Number of pods per plant & $0.584^{*}$ & 0.0301 & 2.72 \\
\hline Number of primary branches & $0.470^{* *}$ & 0.0514 & 9.15 \\
\hline Number of seeds per pod & $0.050^{* * *}$ & 0.003 & 15.13 \\
\hline
\end{tabular}

*, ** Significant at 0.05 and 0.01 level respectively

\subsection{Path coefficient Analysis}

Partitioning path correlation coefficients into direct and indirect effects provides information on the actual contribution of independent variables with respect to a dependent variable. The present study showed a maximum direct effect on yield for the number of pods per plant (NPP), which influences grain yield per plant (GY) directly in a positive direction, followed by number of branches per plant (NPRB), hundred seed weight (HSW), plant height (PH), harvest index (HI) and grain filling period (GFP) (Table 11).

Days to flowering (DF) was negatively correlated with yield per plant (GY). Again, biological yield (BY), number of seed per pod (NSP), days to flowering (DF) and days to maturity (DM) had direct negative effects on yield.

Table 11. Estimation of path coefficients by partitioning phenotypic correlations into direct and indirect effects (bold values indicate the direct effect)

\begin{tabular}{|l|l|l|l|l|l|l|l|l|l|l|l|}
\hline TRAIT & BY & HI & PBRP & NPP & NSP & HSW & PH & DF & DM & GFP & GY \\
\hline BY & $\mathbf{- 0 . 2 7 7}$ & -0.0120 & 0.472 & -0.128 & -0.0401 & -0.0399 & 0.0495 & 0.2756 & 0.0692 & -0.0120 & $0.92^{* *}$ \\
\hline HI & 0.3065 & $\mathbf{0 . 0 4 5 5}$ & -0.1322 & -0.4131 & -0.094 & 0.0610 & 0.0214 & -0.001 & -0.052 & 0.0249 & $0.17^{* *}$ \\
\hline PRBP & 0.0218 & 0.0249 & $\mathbf{1 . 9 7 3}$ & 2.387 & 0.0661 & 0.0728 & -0.0112 & 0.1592 & 0.0966 & 0.0029 & $0.68^{* *}$ \\
\hline NPP & 0.0661 & 0.0246 & 1.640 & $\mathbf{2 . 8 4 8}$ & 0.0661 & 0.0605 & -0.0049 & 0.0905 & 0.0694 & 0.0019 & $0.88^{* *}$ \\
\hline NSP & 0.0401 & -0.0227 & 0.472 & 0.4131 & $\mathbf{- 0 . 2 7 7}$ & 0.00575 & 0.00732 & -0.0427 & 0.0032 & 0.00166 & $0.77^{* *}$ \\
\hline HSW & 0.1381 & 0.0232 & 1.067 & 1.452 & 0.1381 & $\mathbf{0 . 0 7 2 8}$ & 0.00154 & 0.3065 & 0.0327 & 0.00166 & $0.27^{* *}$ \\
\hline PH & -0.302 & 0.0010 & -0.1461 & -0.1310 & -0.0303 & -0.0122 & $\mathbf{0 . 0 6 7}$ & -0.749 & -0.0398 & 0.00004 & $0.55^{* *}$ \\
\hline DF & -0.0119 & -0.014 & -0.1796 & -0.0119 & -0.0119 & -0.0116 & 0.0505 & $\mathbf{- 0 . 9 9 5}$ & -0.0502 & -0.00135 & $-0.30^{* *}$ \\
\hline DM & 0.0072 & -0.0119 & 1.097 & -1.581 & 0.0072 & 0.0563 & 0.0214 & -0.4001 & $\mathbf{- 0 . 1 2 5}$ & -0.0031 & $0.26^{* *}$ \\
\hline GFP & 0.0155 & 0.1381 & -0.1461 & 0.0072 & -0.0174 & 0.0655 & -0.0112 & -0.0726 & 0.0779 & $\mathbf{0 . 0 0 4 9}$ & $0.60^{* *}$ \\
\hline Re
\end{tabular}

Residual effect $=0.274$

Note: * and ** indicates significant at $5 \%$ and $1 \%$ probability level, respectively, biological yield pert plant $(g)$ $(B Y)$, grain yield per plant $(\mathrm{g})(G Y)$, plant height $(\mathrm{cm})(P H)$, number of primary branches $(N P R B)$, number of pods per plant(NPP), number of seeds per pod (NSP), Hundred seed weight $(\mathrm{g})$ (HSW), number of days to flower $(D F)$, number of days to maturity $(D M)$, grain filling period $(G F P)$ and harvest index $(H I)$.

\section{DISCUSSION}

The significant differences among soybean genotypes in the investigation indicate the presence of genetic variability in the material used and provide a good opportunity for yield improvement. Grain yield and other characters exhibited stability across the seasons since the significance of genotype $x$ environment interaction was not detected and the differences among genotypes were obvious (Table 4). This appears to show that further improvement through selection for all characters studied could be effective. High ratios of the genotypic variance to phenotypic variance for biological yield, grain yield per plant, number of pods per plant, number of seeds per pod, hundred seed weight, plant height, flowering date, maturity date and grain filling period indicate the existence of immense inherent variability that remains unaltered by environmental conditions among the genotypes, which in turn is more useful for exploitation in selection and hybridization programs.

Although the genotypic coefficient of variation showed the extent of genetic variability present in the genotypes for various traits, it does not provide full scope to assess the variation that is heritable. Heritable variation is useful for permanent genetic improvement [12]. The most important function of the heritability in the genetic study of quantitative characters is its predictive role to indicate the reliability of the phenotypic value as a guide to breeding value [13][14]. The genotypic coefficient of variation along with heritability estimates provide reliable estimates of the amount of genetic advance to be expected through phenotypic selection [15]. High heritability estimates for grain 
yield, number of seeds per pod, plant height and hundred seed weight indicate a high response to selection in these traits [16] and this results were also reported by Dhanwani [17] and Rashid [18] which support the present findings. Heritability and genetic advance are important selection parameters. The estimate of genetic advance is more useful as a selection tool when considered jointly with heritability estimates [19]. The estimates of genetic advance help in understanding the type of gene action involved in the expression of various polygenic characters. High values of genetic advance are indicative of additive gene action whereas low values are indicative of non-additive gene action [19]. Thus the heritability estimates will be reliable if accompanied by high genetic advance.

High heritability accompanied with high genetic advance as percent of the mean in case of grain yield per plant, number of seeds per pod, biological yield, plant height, grain filling period, hundred seed weight and number of primary branches indicate that these are simply inherited traits and most likely the heritability is due to additive gene effects and selection may be effective in early generations for these traits. Similar findings have been reported by some authors [18]. However, maturity date, flowering date and harvest index had high heritability coupled with low genetic advance indicates non-additive gene effects.

From the above discussion, hundred seed weight, grain yield per plant, number of seeds per pod, biological yield, and plant height were shown to have high to moderate genotypic variance, high to moderate heritability and greater genetic gain. Selection can therefore be based on these characters and their phenotypic expression would be a good indicator of their genotypic potentiality. The remaining traits recorded lower scores in the three genetic parameters considered in this study and therefore offered less scope for selection as they were much more under the influence of the environment. An understanding of inter-character correlation is essential to successful selection of useful genotypes from the whole population but intensive selection for any characteristic might result in losses in others [19]. The magnitude of the genotypic and phenotypic correlations and their utilization in the selection had been stated by a number of researchers [20] [21]. Genotypic correlation coefficient offers a measure of the genetic association between characteristics and may provide an important criterion of the selection procedures [22]. Genotypic correlation coefficient values were greater for most of the characters than their corresponding phenotypic correlation coefficient values, indicating inherent association of the characters. Positive significant associations were obtained between grain yield and plant height because these tall lines generally excelled in their capacity to support seed growth by stem reserve mobilization [23]. Therefore, selection for tall plants tends to increase grain yield per plant. The present study suggests that a positive association between grain yield and grain filling period and a negative association with days to flowering were obtained. Previous studies have confirmed this result by Dilnesaw [20] and Sureshrao [24], which means that early flowering genotypes with adequate grain filling period escape terminal moisture stress and, thus give better grain yield. The yield components exhibited varying trends of association among themselves. Plant height showed positive significant correlations with number of seed per pod. The significant positive correlation of plant height with number of seed per pod has been reported by Islam [22]. To evaluate the correlation between variables, it is important to number of seed per pod this "magnitude" or "strength" as well as the significance of the correlation. It expresses the amount of common variation between the two variables. The estimate of determination $\left(\mathrm{R}^{2}\right)$ indicates that the total variability accounted by all the characters considered together was $96 \%$, whereas $36 \%$ of the total variability for yield per plant could be accounted if selection was based only on number of pods per plant, number of primary branches and number of seeds per pod indicating that more emphasis should be laid on the improvement of these two components for increasing the grain yield in soybean.

Partitioning path correlation coefficients into direct and indirect effects provides information on the actual contribution of independent variables with respect to a dependent variable. The present study showed a maximum direct effect on yield for the number of pods per plant (NPP), which influences grain yield per plant (GY) directly in a positive direction, followed by number of branches per plant (NPRB), hundred seed weight (HSW), plant height (PH), harvest index (HI) and grain filling period (GFP) (Table 11). These characters have direct positive effects on yield per plant (GY), indicating that these are the main contributors to yield for soybean plants. Therefore, during phenotypic selection the main emphasis should be given to these traits for producing high yielding soybean genotypes. These results are in agreement with other studies of Malik [25\} and Jain [26]. 
Days to flowering (DF) was negatively correlated with yield per plant (GY). Again, biological yield (BY), number of seed per pod (NSP), days to flowering (DF) and days to maturity (DM) had direct negative effects on yield. This result demonstrates that for soybean selection on the basis of these traits might lead to a yield compromise [27]. Sharma [28] reported that days to maturity and days to flowering contributed mostly to the seed yield. Differences between studies might be due to the influence of environmental factors [27]. Biological yield (BY), number of seed per pod (NSP) and days to maturity $(\mathrm{DM})$ were positively correlated with yield per plant $(\mathrm{GY})$, but the direct effect on yield per plant $(\mathrm{GY})$ was positive. This negative effect could be due to the fact that any negative indirect effects nullified any direct positive effects that biological yield (BY), number of seed per pod (NSP) and days to maturity (DM) might have on yield. The residual effect on seed yield/plant was low and this indicates that the traits under study could be used to determine any effects on seed yield [29]. The above information suggests that a highly significant positive correlation, with the highest positive direct effect were observed for the number of pods per plant (NPP) followed by the number of primary branches per plant (NPBP). Therefore, the number of pods per plant (NPP) and number of primary branches per plant (NPBP) can be considered as critical criteria for improving yield. Similar conclusions were found in other studies [25] [26].

\section{Conclusion}

The present study showed that grain yield per plant had strong and positive genotypic correlation with number of pods per plant, number of primary branches and number of seeds per pod. Multiple correlations indicated that the total variability accounted by these traits was $36.38 \%$. Regression analysis also indicated number of pods per plant, number of primary branches and number of seeds per pod as the most effective variables contributing to the grain yield. So, it is concluded that these three traits may be considered as the selection criteria for the improvement of grain soybean.

Yield in soybeans is a complex polygenic character, so direct selection based on yield might not give positive results without giving due consideration to genetic background. Importantly, correlation analysis can help when examining selection criteria for improving yield through indirect selection of its component traits, which are highly correlated. Considering the inter-relationships studied and path analysis of the various component characters with seed yield and among themselves, it is clear that number of pods per plant (NPP), number of branches per plant (NPRB), hundred seed weight (HSW), plant height $(\mathrm{PH})$, harvest index (HI) and grain filling period (GFP) are important traits to be considered when breeding to improve the yield of soybean.

\section{ACKNOWLEDGMENTS}

We appreciate the IITA and Pawe Agricultural research Center for the support extended to this investigation.

\section{REFERENCES}

[1] FAO., 2012. FAOSTAT, FAO Statistical Data Bases-agriculture (available at http:// apps. fao. org.). http://faostat.fao.org/ FAOSTAT.

[2] CSA., 2012. Agricultural Sample Survey Statistical Bulletins. Central Statistical Authority, Addis Ababa, Ethiopia.

[3] Aditya J.P., Pushpendra B.P., and Anuradha B., 2011, Genetic variability, heritability and character association for yield and component characters in soybean (G. $\max (\mathrm{L}$.) Merrill), Journal of Central European Agriculture, 12(1): 27-34 https://doi.org/10.5513/JCEA01/12.1.877

[4] Agong S.G., Schittenhelm S., and Fried W., 2001, Genotypic variation of Kenyan tomato (Lycopersicon esculentum Mill.) germplasm, Journal of Food Technology in Africa, 6(1): 13-17 https://doi.org/10.4314/jfta.v6i1.19277

[5] Akinyele B.O., and Osekita O.S., 2006, Correlation and path coefficient analyses of seed yield attributes in okra [Abelmoschusesculentus (L.) Moench], African Journal of Biotechnology, 5(14): $1330-1338$

[6] Akhter T., Ivy N.A., Rasul M.G., and Mian M.A.K., 2010, Variability and character association of reproductive traits in exotic rice germplasm, Bangladesh Journal of Plant Breeding and Genetics, 23(1): 39-43 
[7] Ali A., Iqbal Z., Safdar M.E., Ashraf M., Aziz M., Asif M., Mubeen M., Noorka I.R., and Rehman A., 2013, Comparison of yield performance of soybean varieties under semi-arid condition, Journal of Animal and Plant Science, 23: 828-832

[8] Anwar M.F., and Aditya ., 2013, Evaluation of genetic diversity in soybean (Glycine max L.) genotypes based on agronomic and biochemical traits, Pakistan Research Repository, 188

[9] Chandel K.K., Patel N.B., and Patel J.B., 2013, Genetic variability analysis of soybean (Glycine $\max ($ L.) Merrill), AGRES-An International e-Journal, 2: 318-325

[10] Arshad W., Zeeshan M., Khan M.I., Ali S., Hussain M., and Rahman S.U., 2014, Character association and causal effect analysis for yield and yield components among early maturing genotypes of soybean (Glycine $\max (\mathrm{L}$.) Merrill), Journal of Renewable Agriculture, 2: 1-4 https://doi.org/10.12966/jra.03.01.2014

[11] Baraskar V.V., Kachhadia V.H., Vachhanl J.H., Barad H.R., Patel M.B., and Darwankar M.S., 2014, Genetic variability, heritability and genetic advance in soybean [Glycine max (L.) Merrill], Electronic Journal of Plant Breeding, 5: 802-806

[12] Baruah S., Sarma M.K., Baishya D., Sharma A.A., Borah R., and Bhuyan J., 2014, Genetic variation for seed yield and yellow mosaic virus resistance in soybean [Glycine max (L.) Mill.], International Journal of Scientific and Research Publications, 4: 1-10

[13] Dabholkar, A.R. (1992). Elements of biometrical genetics. Concept Publishing Company, New Delhi, India.

[14] Falconer, D.S., \& Mackay, T.F.C. (1996). Introduction to quantitative genetics. 4th Edn., Benjamin Cummings, England, ISBN-10 : 0582243025.

[15] Burton, G.W. (1952). Quantitative inheritance in grasses .Proc.6th. Intl. Grassland Congr. 1, 277-283.

[16] Basavaraj B.L., Vilas G.D., and Vijayakumar R., 2015, Study on genetic variability and character inter-relation of quality and yield components in tomato (Solanum lycopersicum L.), Hort. Flora Research Spectrum, 4(2): 108-115

[17] Dhanwani R.K., Sarawgi A.K., Solanki A., and Tiwari J.K., 2013, Genetic variability analysis for various yield attributing and quality traits in rice $(O$. sativa $\mathrm{L}$.), The Bioscan: An International Quarterly Journal of Life Science, 8(4): 1403-1407

[18] Ghodrati G., 2013, Study of genetic variation and broad sense heritability for some qualitative and quantitative traits in soybean (Glycine $\max$ L.) genotypes, Journal of Current Opinion in Agriculture, 2: 31-35

[19] Johnson, H.W, Robinson, H.E., Comstock, R.E. (1995). Estimates of genetic and environmental variability in soybean. Agron J, 47, 314-318 http://dx.doi.org/10.2134/agronj1955. $00021962004700070009 x$

[20] Dilnesaw Z., Abady S., and Getahun A., 2013, Genetic variability and heritability of soybean [Glycine max (L.) Mill.] genotypes in Pawe district, Metekel zone, Benishangule Gumuz regional state, north-western Ethiopia, Wudpecker Journal of Agricultural Research, 2: 240-245

[21] Ghodrati G., 2013, Study of genetic variation and broad sense heritability for some qualitative and quantitative traits in soybean (Glycine $\max$ L.) genotypes, Journal of Current Opinion in Agriculture, 2: 31-35

[22] Islam M.A., Raffi S.A., Hossain M.A., and Hasan A.K., 2015, Analysis of genetic variability, heritability and genetic advance for yield and yield associated traits in some promising advanced lines of rice, Progressive Agriculture, 26: 26-31https://doi.org/10.3329/pa.v26i1.24511

[23] Mohsen A.E., Ashraf A., Mahmoud G.O., and Safina S.A., 2013, Agronomical evaluation of six soybean cultivars using correlation and regression analysis under different irrigation regime conditions, Journal of Plant Breeding and Crop Science, 5: 91-102 https://doi.org/10.5897/JPBCS2013.0389

[24] Sureshrao S.S., Singh V.J., Gampala S., and Rangare N.R., 2014, Assessment of genetic variability of the main yield related characters in soybean, International Journal of Food, Agriculture and Veterinary Sciences, 4: 69-74

[25] Malik M.F.A., Qureshi A.S., Ashraf M., and Ghafoor A., 2006, Genetic variability of the main yield related characters in soybean, International Journal of Agriculture and Biology, 8: 815-819 
[26] Jain S., Srivastava S.C., Singh K.S., Indapurkar Y.M., and Singh B.K., 2015, Studies on genetic variability, character association and path analysis for yield and its contributing traits in soybean [Glycine max (L.) Merrill], Agricultural Research Communication Center, Legume Research, 38(2): 182-184 https://doi.org/10.5958/0976-0571.2015.00031.4

[27] Malik M.F.A., Muhammad A., Qureshi A.S., and Abdul G., 2007, Assessment of genetic variability, correlation and path analyses for yield and its components in soybean, Pakistan Journal of Botany, 39: 405-413

[28] Sharma S.M., Rao S.K., and Goswami U., 1983, Genetic variation, correlation and regression analysis and their implications in selection of exotic soybean, Mysore Journal of Agricultural Sciences, 17(1): 26-30

[29] Chandel K.K., Patel N.B., and Patel J.B., 2014, Correlation and path analysis of soybean (Glycine max (L.) Merrill). AGRES-An International e-Journal, 3: 25-31. 